\title{
PENGARUH MODEL PEMBELAJARAN APTITUDE TREATMENT INTERACTION (ATI) UNTUK MENINGKATKAN HASIL BELAJAR PKn SISWA KELAS VII MTS AR-RISYDINY SEGAET DESA WAKAN KEC.JEROWARU LOMBOK TIMUR
}

\author{
H. KAMALUDDIN, HA. \& SUMARNIWATI \\ (Dosen PNS DPK Kopertis Wilayah VIII)
}

INFO ARTIKEL
Riwayat Artikel:
Diterima: 04-09-2016
Disetujui: 30-09-2016
Kata Kunci:
$\begin{aligned} & \text { Aptitude treatment } \\ & \text { interaction (ATI) Untuk } \\ & \text { meningkatkan hasil } \\ & \text { belajar. }\end{aligned}$

\section{A. LATAR BELAKANG}

Pendidikan adalah investasi sumber daya manusia jangka panjang yang mempunyai nilai strategis bagi kelangsungan peradapan manusia di dunia. Oleh sebab itu, hampir semua negara menempatkan variabel pendidikan sebagai sesuatu yang penting dan utama dalam konteks pembangunan bangsa dan negara. Begitu juga Indonesia menempatkan pendidikan sebagai sesuatu yang penting dan utama. Hal ini dapat dilihat dari isi Pembukaan UUD 1945 alenia IV yang menegaskan bahwa salah satu tujuan nasional bangsa Indonesia adalah mencerdaskan kehidupan bangsa.

Kondisi pembelajaran semacam ini masih dialami di sekolah-sekolah lingkungan kita, seperti proses belajar mengajar yang terjadi di kelas VII MTs Ar-Rusydiny Segaet.
Dari pengamatan awal dilokasi penelitian bahwa model pembelajaran yang diterapkan guru selama ini masih terbatas pada model-model pembelajaran yang menjenuhkan siswa dalam belajar yang berakibat pada penurunan minat dan motivasi belajar sehingga berdampak pada penurunan hasil belajar siswa.

Pencapaian tujuan pembelajaran juga dipengaruhi oleh berbagai faktor, salah satu diantaranya adalah menggunakan model pembelajaran yang kurang variatif. Keberhasilan dari suatu proses belajar seorang siswa dapat dilihat dari hasil belajar yang dihasilkan.

Pembelajaran Aptitude Treatment Interaction (ATI) adalah sebuah pendekatan dalam pembelajaran yang berusaha mencari dan menemukan perlakuanperlakuan (treatment) yang cocok dengan perbedaan kemampuan (aptitude) siswa, yaitu perlakuan (treatments) yang secara optimal efektif diterapkan untuk peserta didik yang berbeda tingkat 
kemampuannya, Gronbach dalam Ramayulis ( 2012: 235).

Pembelajaran (treatment) yang diterapkan dengan perbedaan kemampuan (aptitude) siswa, maka hasil belajar siswa semakin optimal. Berdasarkan latar belakang di atas, maka peneliti merasa tertarik untuk mengadakan penelitian tentang "Pengaruh Model Pembelajaran Aptitude Treatment Interaction (Ati) Untuk Meningkatkan Hasil Belajar PKn Siswa Kelas VII di MTs Ar-Rusydiny Segaet Tahun Pelajaran 2014/2015.

\section{B. METODE PENELITIAN}

\section{Jenis penelitian}

Adapun jenis penelitian yang digunakan dalam penelitian ini adalah, penelitian Kuantitatif. Sementara kedekatan yang di gunakan yaitu pendekatan eksperimen. Karena gejala yang diteliti dalam penelitian ini sengaja diadakan berupa pemberian pembelajaran dengan menggunakan model pembelajaran aptitude treatment interaction (ATI) kepada kelas eksperimen

Desain penelitian ini adalah Pre-experimental design dalam bentuk One- Group Pretest- posttest Design, dalam desain ini terdapat satu kelompok yang dipilih secara random, kemudian diberi pre-test untuk mengetahui keadaan awal adakah perbedaan sebelum dan sesudah perlakuan (treatment).

Gambar design nya sebagai berikut :

\begin{tabular}{|c|c|c|}
\hline Pre-test & Perlakuan & Post-tes \\
\hline O1 & $\mathrm{X}$ & $\mathrm{O} 2$ \\
\hline
\end{tabular}

Design one group

$\mathrm{O} 1 \mathrm{X} \quad \mathrm{O} 2$

Keterangan :

O1 : Nilai tes awal

$\mathrm{X}$ : Treatment atau

perlakuan

O2 : Nilai tes akhir setelah diberikan treatment (Arikunto, 2013: 85)

\section{Lokasi dan Waktu Penilitian}

lokasi yang di jadikan sitting penelitian adalah MTs Ar-Rosidin Segaet.

\section{a. Populasi dan Sampel Penelitian}

Menurut Arikunto (2006: 130) populasi adalah keseluruhan subyek penelitian. Populasi adalah wilayah generalisasi yang terdiri atas obyek dan subyek yang mempunyai kualitas dan karakter tertentu yang ditetapkan oleh peneliti untuk dipelajari kemudian ditarik kesimpulannya sugiyono ( 2013:80) Populasi itu sendiri diterjemahkan sebagai sekelompok individu yang memiliki ilmu pengetahuan yang luas atau karakteristik umum yang menjadi pusat penelitian Sanafiah Faesal ( 2002: 28) Sedangkan menurut Margono (2007: 56) Populasi adalah seluruh data yang menjadi perhatian kita dalam suatu ruang lingkup dan waktu yang kita tentukan.

Dari pendapat beberapa para ahli diatas dapat penulis simpulkan populasi adalah semua keseluruhan objek, subjek, individu atau peristiwa lengkap, jelas dan diamati yang memiliki sifat-sifat yanng sama serta memenuhi syarat-syarat tertentu dalam suatu penelitian.

Sehubungan dengan definisi populasi itu, maka yanng menjadi populasi penelitian ini adalah seluruh siswa kelas VII MTs.Ar-Rusidiny Segaet tahun pelajara 2014/2015 yang berjumlah 29 orang siswa. Mengingat jumlah populasi yang relatif terbatas, maka penelitian penentuan subjek ini dilakukan dengan mempergunakan penelitian populasi. Hal ini didasarkan pada suatu pendapat yang menyebutkan bahwa untuk sekedar ancer-ancer maka apabila subjeknya kurang dari 100, lebih baik diambil semua populasi dalam penelitian ini adalah kelas VII MTs.Ar-Rosidiny Segaet sehingga penelitiannya merupakan penelitian populasi" Suharsimi ( 2004: 120)

\section{b. Metode Pengumpulan Data}

\section{Metode Tes}

Dalam penelitian ini metode yang akan digunakan adalah metode tes. Metode tes adalah alat prosedur yang digunakan, alat ini berbentuk tugas-tugas atau suruhan-suruhan yang di laksanakan dan dapat berupa pertanyaan-pertanyaan atau soal-soal yang harus dijawab. Adapun pelaksanaan dan dilaksanakan secara lisan maupun tulisan(Nurkancana dan Sunartana, 2004: 25) Tes ialah seperangkat rangsangan (stimuli) yang diberikan kepada seseorang dengan maksud untuk mendapat jawaban yang dapat menjadikan skor angka (Margono, 2012 : 170). Adapun jenis tes yang umumnya dikenal dan digunakan sebagai alat pengukuran adalah tes lisan dan tes tertulis. Sejalan dengan itu pada penelitian ini lebih menghkususkan pada penggunaan tes tertulis.

Dari ke dua pendapat diatas, metode tes adalah suatu alat prosedur yang sistematis dan obyektif untuk memperoleh data-data atau keterangan yang diinginkan tentang seseorang dengan cara memberikan pertanyaan soal atau serangkaian suatu tugas untuk dikerjakan. Sehubungan dengan penilaian ini metode tes, untuk mengetahui data tentang pengaruh model pembelajaran Aptitude Treatment Interaction hasil belajar belajar PKn siswa kelas VII MTs Ar-Rusydiny Segaet Lombok Timur Tahun Pelajaran 2013/2014.

Dalam peneltian ini tes hasil belajar yang digunakan adalah dalam bentuk obyektip soal pilihan ganda yang berjumlah 20 butir yang diambil dari buku paket pedoman pada KTSP dan disetujui oleh guru pendidikan kewarganegaraan (PKn). Instrument ini disusun untuk mengetahui sejauh mana tingkat pemahaman siswa dalam menguasai materi yang telah disampaikan melalui pembelajaran Aptitude Treatment Interaction Untuk Meningkatkan hasil belajar siswa di kelas VII MTs Ar-Rusydiny Segaet Lombok Timur

Untuk memperoleh data seperti yang dimaksud, maka teknik atau metode yang akan digunakan dalam penelitian ini adalah metode dalam bentuk obyektip tes pilihan ganda, yakni tes awal (pretes) dan tes akhir (posttest)

Tes Awal (Pretest)

Pretes ini dilakukan untuk mengetahui kemampuan awal hasil belajar siswa pada mata pelajaran PKn dari siswa sebelulum memperoleh perlakuan. Butir soal tes diadaptasi dari buku penunjang PKn kelas VII dengan bentuk soal objektif 20 butir. Pelajaran PKn disimak oleh siswa diadptasi/disesuaikan dengan tujuan pembelajaran yang ditetapkan.

\section{a. Tes Akhir (Posttest)}


Tes hasil belajar PKn dilakkukan untuk mengukur perolehan hasil belajar pada akhir pelajaran pelajaran dengan menggunakan instrument tes sistematis yang dibuat oleh guru. yang diadaptasikan dari soal yang disusun oleh MGMP (Musyawarah Guru Mata Pelajaran) berdasrkan silabus PKn semester 1 kelas VII MTs Ar-Rusydiny Segaet.

\section{Instrumen Penelitian}

Instrumen dalam penelitian ini memiliki kedudukan yang sangat penting, karena instrument sangat menentukan kelancaran dan validnya hasil penelitian.

Instrumen penelitian adalah alat atau fasilitas yang digunakan oleh peneliti dalam mengumpulkan data agar pekerjaannya lebih mudah dan hasilnya lebih baik, dalam arti lebih cermat, lengkap, dan sistematis, sehingga lebih mudah diolah Arikunto, (2010: 203).

Instrumen yang digunakan dalam penelitian ini adalah tes soal pilihan ganda,suatu penelitian yang layak digunakan sebagai alat ukur,apabila telah dilakukan uji validitas dan rebilitasnya Arikunto ( 2006 :105 )

\section{a .Uji Validitas}

Uji validitas validitas digunakan untuk mengetahui tingkat kevalidan atau kesahihan masingmasing 20 butir soal berbentuk objektip soal Tes pilihan ganda. Sehingga dapat ditemukan butir soal yang diterima dan yang gagal. Tingkat kevalidan ini dapat dihitung dengan korelasi poin biserial yaitu:

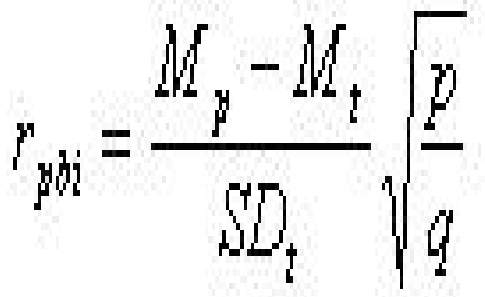

keterangan :

$\mathrm{r}_{\mathrm{pbi}}=$ Koefisien korelasi korelasi antara variable I dengan variable II.

$\mathrm{M}_{\mathrm{p}} \quad$ = Skor rata-rata hitung yang dimiliki oleh testee, yang untuk butir item yang bersangkutan telah dijawab dengan betul.

$\mathrm{M}_{\mathrm{t}}=$ Skor rata-rata dari skor total.

$\mathrm{SD}_{\mathrm{t}}=$ Deviasi standar dari skor total.

$\mathrm{P} \quad=$ Proporsi testee yang menjawab betul terhadap butir item yang sedang diuji validitas itemnya.

$\mathrm{q}=$ Proporsi testee yang menjawab salah terhadap buitr item yang sedang diuji validitas itemnya.,

(Anas Sudijono, 2005:120)

\section{Uji Reliabilitas}

Reliabilitas menunjukkan suatu pengertian bahwa suatu instrumen cukup dapat dipercaya sebagai alat untuk pengumpulan data. Dalam penelitian ini menggunakan rumus $\mathrm{K}-\mathrm{R} 20$ (KR= Kunder dan Ricardson) untuk menemukan reabilitas instrumen sebagai berikut: Rumus jumlah varian butir :

$$
\mathrm{r}_{11}=\left(\frac{K}{K-1}\right) x\left(\frac{V_{t}-\sum p q}{V_{t}}\right)
$$

\section{Keterangan}

$$
\begin{array}{ll}
\mathrm{r}_{11} & =\text { Reliabilitas instrumen } \\
\mathrm{K} & =\text { Jumlah butir pertanyaan }
\end{array}
$$

$$
\begin{array}{ll}
\text { Vol. 4, No. 2, September 2016, hal 22-29 } \\
\begin{array}{ll}
V t & =\text { Varians total } \\
p & =\underline{\text { Proporsi subjek yang }} \\
& \text { mendapat skor } \\
\mathrm{Nq} & =1-\mathrm{p} \\
\sum \mathrm{pq} & =\text { Jumlah perkalian antara p dan q } \\
& \text { (Arikunto, 2013) }
\end{array}
\end{array}
$$

\section{Jenis dan Sumber Data \\ I. Jenis Data}

Menurut Cholid Narbuko (2003: 66), umumnya data terbagi atas data kualitatif dan data kuantitatif. Data kualitatif adalah jenis data yang berbentuk katakata, kalimat atau pendapat dari respoden atau informan penelitian. Sedangkan data kuantitatif data yanng berbentuk angka, atau data kualitatif yang diangkakan (skoring). Namun demikian, data dalam penelitian ini selalu dihubunngkan dengan sekala pengukuran.

Menurut Sundara K., (2010: 22) skala pengukuran dapat berupa yaitu sebagi berikut:

1. Skala nominal, disusun berdasarkan jenis atau kategori seperti : agama yang dianut :Islam (1), Hindu (2), Kristen (3), Budha (4), dan lain-lain.

2. Skala odinal, disusun berdasarkan ranking, seperti mengukur rannking dalam suatu pertandingan, juara I, II, III.

3. Skala interval, adalah skala yang menunjukan jarak antara data dengan data yang lain mempuyai bobot yang sama, seperti hasil belajar dari 1-100, indeks prestasi dari 1-4, dan lain-lain.

4. ........Skala ratio, adalah pengukuran yang mempunyai nilai nol mutlak ol mutlak, dan mempunnyai jarak yang sama (merupakan bilangan yang sebenarnya), seperti ukuran panjang meter ada o meter dan lain-lain.

Dari pendapat tersebut, jenis data kuantitatif yang digunakan dalam penelitian ini adalah data interval yaitu mencari pembeda untuk meningkatkan hasil belajar siswa antara sebelum dan sesudah penggunaan pembelajaran Aptitude Treatment Interaction.

\section{Sumber Data}

Untuk mencari sumber data adalah penting untuk didasari bahwa menurut sifatnya (ditinjau dari tujuan penelitian) kita dapat menggolongkan sumber data itu dalam 2 golongan yakni : Sumber data primer, adalah sumber-sumber yang memberikan data langsung dari tangan pertama. Sumber data sekunder, adalah sumber yang mengutip dari sumber lain Winarno Surakhmad ( 2004: 134).

Sumber data dalam penelitian ini menggunakan sumber data primer dan data skunder. Data primer dalam penelitian ini berupa hasil tes siswa. Sedangkan data skunder dalam penelitian ini adalah hasil penelitian dari hasil dokumen-dokumen.

\section{Identifikasi dan Definisi Operasional Varibel \\ 1. Identifikasi Varibel}

Sutrisno Hadi mendevinisi Variabel sebagai gejala yang bervariasi misalnya jenis kelamin, karena jenis kelamin mempunyai variasi lakilaki -perempuan;berat badan, karena ada berat $40 \mathrm{~kg}$, dan sebagainya. Gejala adalah objek penelitian, sehingga variabel adalah objek variabel yang bervariasi. Menurut Suharsimi Arikunto (2006: 116). Sedangkan Menurut Sundara K, (2010 : 25) Variabel merupakan suatu sifat atau nilai dari orang, subyek atau kegiatan yang mempunyai variasi tertentu yang ditetapkan oleh peneliti. Menurut Suharsimi Arikunto (2006: 118), 
variabel adalah objek penelitian atau apa yang menjadi titik perhatian suatu penelitian.

Dari pendapat para ahli diatas dapat disimpulkan bahwa variabel merupakan suatu gejala atau objek yang akan diteliti dan menjadi suatu titik perhatian dalam penelitian dan merupakan suatu subjek atau kegiatan yang mempunyai variasi tertentu yang ditetapkan oleh peneliti.

Ada dua jenis variabel yaitu : a.) Variabel bebas (Independent Variabel) yaitu variabel yang secara bebas berpengaruh terhadap variabel lain (variabel terikat). Variabel biasanya dilambangkan dengan variabel $\mathrm{X}$. b.) Variabel terikat (Dependent Variabel) yaitu variabel yang dipengaruhi oleh variabel lain (variabel terikat)sehihingga seringkali juga disebut dengan devendent variabel. Variabel ini biasanya dilambangkan dengan variabel Y Suharsimi Arikunto ( 2006: 93)

Dalam penelitian ini varibel $X$ adalah pembelajaran . Aptitude Treatment Interaction. Sedangkan variabel Y adalah hasi belajar PKn siswa kelas V11

\section{Definisi Operasional Variabel}

Variabel yang digunakan dalam penelitian ini adalah pembelajaran dan hasil belajar PKn. Adpun definisi dari masing-masing variabel adalah sebagai berikut :

a. Model pembelajaran Aptitude Treatment Interaction.

Model pembelajaran yang dimaksudkan dalam peneliti Aptitude Treatment Interaction. ini adalah cara menyajikan materi pelajaran yang dilaksanakan melalui kelompok-kelompok kecil (jumlah anggota masingmasing kelompok terdiri dari 3-5 orang ) untuk mengerjakan soal sesuai dengan jawaban.

b. Hasil belajar PKn

Hasil belajar PKn yang dimaksudkan dalam penelitian ini adalah hasil yang dicapai siswa berupa nilai-nilai PKn yang diperoleh melalui kegiatan atau aktifitas belajar sebelum dan sesudah penggunaan model pembelajaran penelit Aptitude Treatment Interaction.

\section{F. Tehnik Analisis Data}

Setelah data diperoleh dari pelaksanaan penelitian, yang dilaksanakan selanjutnya adalah pengujian terhadap data tersebut. Teknik analisa data bertujuan untuk mengelola data yang telah dikumpulkan, sehingga dapat diperoleh suatu kesimpulan, adapun pengujian data adalah sebagai berikut:

\section{a. Uji prasyarat Analisis}

Sebelum dilakukan pengujian hepotesis maka terlebih dahulu dilakukan uji prasyarat analisis berupa uji homogenitas untuk mengetahui apakah varian ke dua sampel tersebut homogen atau tidak

\section{b. Uji Normalitas}

Ada dua cara pengujian normalitas yaitu pengujian normalitas dengan kertas probabilitas normal dan dengan rumus Chi-kuadrat. Dalam penelitian ini peneliti menggunakan rumus Chi-kuadrat.

$$
\chi^{2}=\sum_{i=1}^{k} \frac{\left(f_{o-} f_{n}\right)^{2}}{f_{n}}
$$

Keterangan:

$\chi^{2} \quad=$ chi-kuadrat
$=$ frekuensi yang diobservasi

= frekuensi yang diharapkan

= banyaknya kelas interval

Dengan ketentuan jika ${ }^{2}{ }_{\text {hitung }} \leq \chi^{2}$ tabel pada taraf signifikan $5 \%$ maka populasi berdistribusi secara normal. Bertujuan untuk mengetahui bahwa data berdistribusi normal atau tidak, untuk menghitung normalitas data pada masing-masing variabel $\mathrm{X}$ dan $\mathrm{Y}$. Pada tarafsignifikan $5 \%$ dan derajat kebebasan $(\mathrm{dk})=\mathrm{k}-$ 1, dengan $\mathrm{K}$ adalah panjangkelas, maka kriteria pengujian yang digunakan adalah jikaChi-Kuadrat hitung $\left(\chi_{\text {hitung }}^{2}\right) \leq$ Chi-Kuadrattabel $\left(\chi_{\text {tabel }}^{2}\right)$ berarti varians data homogen dan jika Chi-Kuadrat hitung $\left(\chi_{\text {hitung }}^{2}\right) \geq$ Chi-Kuadrattabel $\left(\chi_{\text {tabel }}^{2}\right)$ berarti varians data tidak homogen.

\section{c. Uji Homogenitas Data}

Sebelum uji $t_{\text {t-tes }}$ digunakan lebih lanjut dilakukan uji homogenitas untuk mengetahui keseragaman varian dari sampel.sampel yang diambil dari populasi yang sama dapat dilakukan Untuk menguji homogenitas varian sampel digunakan rumus Uji-F yaitu:

$$
\mathrm{F}=\frac{\text { Varians terbesar }}{\text { Varians terkecil }}
$$

Homogen atau tidaknya varians data dapat ditentukan dengan membandingkan harga $F_{\text {hitung }}$ dan $F_{\text {tabel. }}$. Jika $\mathrm{F}_{\text {hitung }}>\mathrm{F}_{\text {tabel }}$, maka disimpulkan bahwa varians data bersifat tidak homogen. Sebaliknya jika $F_{\text {hitung }} \leq \mathrm{F}_{\text {tabel }}$, maka disimpulkan bahwa varians data homogen Uji- $t$

\section{d. Uji hipotesis}

Dalam suatu penelitian ilmiah tentu melalui proses analisis data, untuk mendapatkan hasil penelitian yang refresentatif dalam proses pengumpulan datanya, maka langkah peneliti selanjutnya adalah mengolah data tersebut secara statistik. Untuk menarik kesimpulan dari data yang diperoleh, maka analisis yang diterapkan adalah deskriptif kuantitatif dengan rumus treatment $(\mathrm{t})$.

$$
t=\frac{M d}{\sqrt{\frac{\sum \mathrm{x}^{2} \mathrm{~d}}{\mathrm{~N}(\mathrm{~N}-1)}}}
$$

Keterangan :

Md =Mean dari (d) antara post tes dan pre-tes.

$\mathrm{Xd}=$ Jumlah deviasi

$\sum x^{2}=$ Jumlah kuadrat deviasi

$\mathrm{N}=$ Banyaknya subjek

$\mathrm{Db}=$ Ditentukan dengan $\mathrm{N}-1$

(Suharsimi Arikunto,2012: 275).

Rumus $t$ di atas dipergunakan untuk menganalisis hasil eksperimen dari kelompok tunggal (one group) yang diteliti. Menurut Suharsimi A (2006: 275) rumus $(t)$ one group dipergunakan untuk hasil tes awal (pre-tes) dan untuk hasil akhir (post-test) atau menilai hasil tes sebelum dan sesudah perlakuan dari kelomppok eksperimen.

\section{HASIL DAN PEMBAHASAN}

1. Hasil Penelitian 


\section{a) Deskripsi Data Penelitian}

Untuk mendeskripsikan hasil penelitian ini, langkah pertama yang dilakukan adalah pengukuran hasil belajar anak dengan tidak menggunakan Model Pembelajaran Aptitude Traetment Intraction kemudian dikenakan perlakuan untuk jangka waktu tertentu dengan metode Pembelajaran Aptitue Traetment Intraction, lanngkah selanjutnya dilakukan pengukuran lagi kedua kalinya dengan menggunakan tes untuk mendapatkan hasil nilai hasil belajar siswa.

Dalam penelitian ini data yang akan dibahas adalah data tentang hasil belajar siswa yang menggunakan metode lain (sebelum Model Pembelajaran Aptitude Treatment Interaction ) dan hasil belajar siswa yang mengunakan Model Pembelajaran Aptitude Treatment Interaction .

1) Deskripsi Data Penelitian Nilai Hasil belajar siswa (pre-test) sebelum menggunakan model pembelajaran Aptitude Treatment Interaction.

Dari pengamatan awal dilokasi penelitian bahwa model pembelajaran yang diterapkan guru selama ini masih terbatas pada model-model pembelajaran yang menjenuhkan siswa dalam belajar yang berakibat pada penurunan minat dan motivasi belajar sehingga berdampak pada penurunan hasil belajar siswa. Ini terlihat dalam pembelajaran pendidikan kewarganegaraan (PKn) adalah rendahnya perstasi siswa siswi dan sulitnya mengimplentasikan dari nilai raport dua tahun belakangan pada siswa kelas VII pada mata pelajaran PKn nilai rata-rata pada tahun 2012/2013 nilai rata rata siswa kelas VII ,45,65 dan 2013/2014,nilai rata -rata.56,74.hal ini disebabkan kaarna metode dan model pelajaran yang digunakan oleh guru dalam peroses pembelajaran selalu mengunakan paradigma lama yaitu medode ceramah.

Data dalam penelitian ini berupa data hasil belajar. Data hasil belajar ditunjukkan dengan nilai pretest dan posttest, Sebelun Pengambilan data untuk nilai pretest dan posttest dalam penelitian terlebih dahulu dilakukan uji coba untuk mengetahui kelayakan instrumen dalam penelitian ini, dilakukan dengan cara uji coba tes pilihan ganda, maka dalam tabel dibawah ini, data yang telah dikumpulkan akan dideskripsikan sesuai dengan data variabel penelitian, yakni tentang "Sebelum Mengunakan Aptitude Treatment Interaction(ATI) Siswa di MTs Ar-Rusydiny Segaet Lombok Timur Tahun Ajaran 2014/2015. Sebaran frekuensi skor tes hasil Pre-

\begin{tabular}{|c|c|c|c|c|}
\hline No & Interval & $\begin{array}{c}\text { Frekuen } \\
\text { si }\end{array}$ & Fka & Fref \\
\hline 1 & $65-69$ & 2 & 2 & 6,89 \\
\hline 2 & $70-74$ & 9 & 11 & 31,03 \\
\hline 3 & $75-79$ & 7 & 18 & 24,13 \\
\hline 4 & $80-84$ & 6 & 24 & 20,68 \\
\hline 5 & $85-89$ & 3 & 27 & 10,34 \\
\hline 6 & $90-94$ & 2 & 29 & 6,89 \\
\hline \multicolumn{2}{|c|}{ Jumlah } & 29 & & \\
\hline
\end{tabular}
Test (Variabel X) akan diuraikan lebih rinci pada penjelasa

dibawah ini.

Distribusi Frekuensi Tes hasil belajar siswa sebelum menggunakan model pembelajaran Aptitude Treatment Interaction (ATI)

\begin{tabular}{|c|c|c|c|c|}
\hline No & Interval & $\begin{array}{c}\text { Frekuen } \\
\text { si }\end{array}$ & Fka & Fref \\
\hline 1 & $60-64$ & 5 & 5 & 17,24 \\
\hline 2 & $65-69$ & 9 & 14 & 31,03 \\
\hline 3 & $70-74$ & 3 & 17 & 10,34 \\
\hline
\end{tabular}

\begin{tabular}{|c|c|c|c|c|}
\hline 4 & $75-79$ & 7 & 24 & 24,13 \\
\hline 5 & $80-84$ & 5 & 29 & 17,24 \\
\hline \multicolumn{6}{|c|}{ Jumlah } & 29 & & \\
\hline
\end{tabular}

\section{Sumber Data: Diolah}

Selanjut maka, kita lihat Data yang dikumpulkan melalui tes hasil belajar pre-test sebelum menggunakan model aptitude treatment interaction siswa kelas VII dengan jumlah siswa 29, dimana nilai rara-rata siswa sebesar 69,65, Standar Diviansi (simpangan baku) sebesar 1,03, nilai tertinggi sebesar 16 , nilai terendah sebesar 12, modus 70 dan median 73. Perhitungannya dapat dilihat pada (lampiran 9).

Setelah itu untuk mengetahui hasil belajar siswa kelas VII MTs Ar-Rusydiny Segaet, setelah mengggunakan Model Pembelajaran Aptitude Treatment Interaction yaitu dengan cara melakukan tes (Post-test), Setelah itu Menganalisis Data Pos-Test untuk mencari hasil belajar siswa yang memiliki nilai yang tinggi atau rendah dapat kita lihat pada alat pengukur pada (lampiran 6). Setiap skor tes maksimal mendapat nilai 90 dan minimal 65. Tidak ada nilai negatif dalam tes sehingga jawaban yang salah bernilai o. Dari jumlah jawaban yang benar menunjukkan skor mentah anak sesuai jawabannya. Dari nilai tersebut selanjutnya dikonversi menjadi nilai hasil belajar. Dan dari 20 butir soal jumlah nilai benar dibagi jumlah soal dikalikan 100 untuk mendapatkan nilai maksimal, sehingga untuk memperkirakan hasil belajar siswa MTs Ar-Rusydiny Segaet dapat dilihat pada table diatas.

\section{b) Deskripsi Data Penelitian Nilai Hasil belajar siswa(pos-test) sesudah menggunakan model pembelajaran Aptitude Treatment Interaction}

Setelah memberikan tes awal maka, kita lihat Data yang dikumpulkan melalui tes hasil belajar pre-test sebelum menggunakan model aptitude treatment interaction siswa kelas VII dengan jumlah siswa 29, dimana nilai rara-rata siswa sebesar 69,65, Standar Diviansi (simpangan baku) sebesar 1,03, nilai tertinggi sebesar 16, nilai terendah sebesar 12 , modus 70 dan median 73. Perhitungannya dapat dilihat pada (lampiran 9)

Untuk mencari sebaran frekuensi skor hasil belajar pos-tes (Variabel Y) akan diuraikan lebih rinci pada penjelasan dibawah ini. Berikut tabel distribusi frekuensi data hasil belajar dan cara penghitungannya. Dari nilai tes hasil belajar pos-test sesudah menggunakan model Aptitude Treatment Interaction 29 siswa, maka dibuat tabel distribusi frekuensi sebagai berikut.

\section{Distribusi Frekuensi Nilai Hasil Belajar( Pos- Test ) Sesudah Menggunakan model Aptitude Treatment Interaction (ATI)}

\section{Sumber Data: Diolah}

Data yang dikumpulkan melalui hasil belajar pos-test sesudah menggunakan model aptitude treatment interaction , dengan jumlah siswa 29, dimana nilai rara-rata sebesar 75,86, standar diviansi(simpangan baku )sebesar 3,51 nilai tertinggi sebesar 18, nilai terendah sebesar 13, modus 70 dan median 73 . Penghitungannya dapat dilihat pada (Lampiran 8) 


\section{a. Uji Validitas}

Hasil Uji Validitas (lampiran o7) yang terdiri dari 20 butir soal , dimana pengujian dilakukan dengan membandingkan nilai $r$ hitung tiap butir soal dan $r$ tabel . nilai $r$ tabel yang digunakan adalah nilai $r$ pada tarafs signifikan 5\% untuk $\mathrm{N}=29$ yaitu 0,312 dengan kareteria diperoleh 20 butir soal yang valid. Setelah itu

baru dibandingkan dengan harga korelasi yakni $\mathrm{r}_{\mathrm{pbis}}=0,0486$ sehingga dapat dikatakan bahwa untuk butir soal nomor 1 dinyatakan valid.

\section{b. Uji Reliabilitas}

Setelah diperoleh harga $r_{11}$ kemudian dikonsultasikan dengan $\mathrm{r} \quad{ }_{x y}$ dengan interval kepercayaan $95 \%$ jika $\mathrm{r}_{11}>\mathrm{r}_{x y}$ maka soal tersebut dikatakan reliabel.

Hasil Uji Reliabilitas (Lampiran 11) Membandingkan rhitung $=7,996$ sedangkan rtabel $=0,312$ dengan demikian maka soal instrument dapat disimpulkan reliabel.

\section{c. Uji Prasyarat Analisis}

Nilai kelas eksperimen dapat dikatakan homogen jika nilai $F_{\text {hitung }}$ lebih kecil nilai Ftabel ( $F_{\text {hitung }}<$ Ftabel) pada taraf signifikan $5 \%$ dari data diatas diperoleh nilai Ftabel $=2,54$ dan Fhitung $<=$ jadi Fhitung $=1,186<$ Ftabel berdasarkan keteria yang ada, jika Fhitung < Ftabel maka pre-test dan pos test kelas eksperimen dapat dikatakan memiliki varian yang sama, yang menandakan kedua kelas eksperimen homogen pada tarap signifikan 5\%. Dapat dilihat pada(Lampiran 9)

\section{d. Uji Normalitas}

Sebelum dilakukan uji hipotesis terlebih dahulu dilakuan uji normalitas untuk menentukan statistik apa yang harus digunakan dalam menguji hipotesis. Uji normalitas data hasil belajar dilakukan dengan cara menbandingkan harga ( $x^{2}$ hitung) dengan ( $x^{2}$ tabel) pada taaraf signifikan $5 \%$.

Berdasarkan dari hasil pengujian data setelah penggunaan model pembelajaran Aptitude Treatment diperoleh Chi Kuadrat hitung ( $X^{2}$ hitung) $=28$ pada taraf signifikan $5 \%$ dan $\mathrm{dk}=$ jumlah kelas $-1=6-1=5$ didapat harga $X^{2}$ tabel $=42,557$ jadi perhitungan di atas didapatkan $X^{2}$ hitung $<X^{2}$ tabel . Maka distribusi data kelas eksperimenl dapat dinyatakan terdistribusi normal. Dapat dilihat pada (Lampiran 10).

\section{e. Uji Homogenitas}

Uji homogenitas dilakukan untuk menyelidiki apakah data pretest dan posttest pada kedua subjek mempunyai varians yang sama atau tidak.

Berdasarkan hasil perhitungan uji homogenitas pada keduanya kelas diperoleh bahwa $F_{\text {hitung }}=1,186$ dan Ftabel $=2,54$ pada taraf signifikan $5 \%$. Data tersebut menunjukkan bahwa $F_{\text {hitung }}<F_{\text {tabel }}$. Berdasarkan kriteria yang ada, jika $F_{\text {hitung }}<F_{\text {tabel }}$ maka kedua kelas dapat dikatakan homogen pada taraf signifikan 5\%. Dengan demikian, data kemampuan awal (pretest) dan hasil belajar PPKn siswa (posttest) dinyatakan homogen. (perhitungan selengkapnya dapat dilihat pada Lampiran 17)

\section{f. Pengujian Hipotesis}

Sebelum penulis menetapkan apakah hipotesis diterima atau ditolak, maka terlebih dahulu akan ditentukan derajat kebenarannya. Derajat kebenaran dengan rumus : $\mathrm{db}=\mathrm{N}-1=29-1=28$. Dalam melakukan penellitian experiment ini peneliti tentu sangat berharap bahwa perlakuan yang dilakukan yakni Penggunaan Model Pembelajaran Aptitude Treatment Interaction sebagai model pembelajaran akan mendapatkan hasil belajar yang positif sehingga pada pengujian hipotesis yang dilakukan dengan taraf signifikan 5\%, maka nilai ttabel sebesar 2,048 dan nilai thitung sebesar 12,23 . Oleh karena $t_{\text {hitung }}$ lebih besar dari $t_{\text {tabel }}$. Dari hasil tersebut berarti hipotesis yang berbunyi : "Terdapat Pengaruh Penggunaan Model Pembelajaran Aptitude Treatment Interaction Terhadap Hasil Belajar Siswa Pada Bidang Studi PKn Di Kelas VII MTs Ar-rusydiny Segaet Lombok Timur Tahun 2014/2015" diterima. Sedangkan nihil yang berbunyi " Terdapat ada Pengaruh Penggunaan Model Pembelajaran Aptitude Treatment Interaction Terhadap M Hasil Belajar Siswa Pada Bidang Studi PKn Di Kelas VII MTs Ar- Rusydiny Segaet Lombok Timur Tahun 2014/2015" diterima

\section{B.PEMBAHASAN}

Berdasrkan hasil penelitian maka dapat disimpulkan ada pengaruh signifikan 5 penerapkan model Pembelajaran Aptitude Treatment Interaction (ATI) dikelas VII Mts. Ar-Rusydiny Segaet lombok Timur Tahun Permbelajara 2014/2015.

Terdapat Ada Pengaruh Dalam melakukan penellitian experiment ini peneliti tentu sangat berharap bahwa perlakuan yang dilakukan yakni Penggunaan Model Pembelajaran Aptitude Treatment Interaction sebagai model pembelajaran akan mendapatkan hasil belajar yang positif sehingga pada pengujian hipotesis yang dilakukan dengan pengujian dua ekor dengan taraf signifikan 5\%, maka nilai "t" pada tabel yaitu 2,048 dan nilai " $t$ " hasil belajari analisis adalah 12,23 oleh karena itu " $t$ " hasil belajar analisa lebih besar dari nilai tabel. Dari hasil tersebut berarti hipotesis yang berbunyi : "Ada Pengaruh Penggunaan Model Pembelajaran Aptitude Treatment Interaction Untuk Meningkatkan Hasil Belajar Siswa Pada Bidang Studi PPKn Di Kelas VII MTs Ar-rusydiny Segaet Lombok Timur Tahun 2014/2015" diterima. Sedangkan nihil yang berbunyi " ada Pengaruh Penggunaan Model Pembelajaran Aptitude Treatment Interaction Untuk Meningkatkan Hasil Belajar Siswa Pada Bidang Studi PPKn Di Kelas VII MTs Ar- Rusydiny Segaet Lombok Timur Tahun 2014/2015” ditolak.

Aptitude Treatmen Interaction adalah sebuah pendekatan dalam pembelajaran yang berusaha mencari dan menemukan perlakuan-perlakuan (treatment) yang cocok dengan perbedaan kemampuan (aptitude) siswa, yaitu perlakuan (treatments) yang secara optimal efektif diterapkan untuk peserta didik yang berbeda tingkat kemampuannya (Gronbach dalam Ramayulis, 2012: 235) merupakan pembelajaran yang menuntut atau mengajak siswa untuk belajar aktif, dan bertujuan agar siswa bisa lebih mandiri dalam belajar serta menumbuhkan daya kretivitas. Dalam pembelajaran ini guru hanya bertindak sebagai fasilitator, mediator dan motivator yang membantu siswa agar proses pembelajaran berjalan dengan lancar,model pembelajaran ini dapat meningkatkan hasil belajar siswa Karena siswa secara langsung mengaplikasikan apa yang 
28 CIVICUS I Pendidikan Pancasila dan Kewarganegaraan dipelajari, sehingga dapat meningkatkan hasil belajar PPKn siswa yang dibuktikan dengan memberikan tes kemampuan kognitif siswa. Berbeda halnya dengan model pembelajaran konvensional yang hanya menekankan pada guru, guru yang lebih aktif, sementara siswa hanya mendengarkan apa yang di sampaikan oleh guru, model pembelajaran seperti ini yang membuat hasil belajar siswa menjadi lebih minim.

Berdasarkan Pre-test dan Post-test siswa diperoleh nilai rata-rata untuk hasil pre test sebesar 69,66,dan varian sebesar,194,072 Sedangkan untuk hasil pos test diperoleh nilai rata-rata 75,86 ,dan varian sebesar 230, 189 Kedua data tes awal diolah dengan uji $F$ dan menghasilkan $F_{\text {hitung }}<F_{\text {tabel }}$, dimana nilai $F_{\text {hitung }}$ sebesar 1,186dan $F_{\text {tabel }}$ sebesar 2,54 (1,186<2,54) yang menghasilkan dua kelas eksperimen homogen pada taraf signifikan 5\%. Hal ini berarti tidak ada perbedaan kemampuan awal kedua kelas eksperimen.

Dengan demikian dapat ditarik kesimpulan bahwa ada perbedaan antara model pembelajaran Aptitude Treatment Interaction dengan model pembelajaran Konvensional tehadap peningkatan hasil belajarar PKn siswa kelas X MTs Ar-Rusydiny Segaet Lombok Timur Tahun Pelajaran 2014-2015.

\section{SIMPULAN DAN SARAN}

\section{Kesimpulan}

Berdasarkan hasil penelitian dan hasil analisa data yang dilakukan, maka peneliti dapat menarik kesimpulan bahwa adanya peningkatan hasil belajar siswa pada pelajaran PKn siswa kelas VII MTs ARusydiny Segaet tahun pelajaran 2013/2014 setelah diterapkan model pembelajaran Aptitude Treatment Interaction . Dapat dirumuskan yaitu :

a) Dalam taraf signifikan $5 \%$ nilai " $\mathrm{t}$ " tertera bilangan sebesar 2,045 oleh karena bilangan yang sebesar 12,23, lebih besar dari bilangan yang ada dalam tabel maka hipotesis kerja yang diajukan dalam penelitian ini berbunyi "Adanya pengaruh model pembelajaran Aptitude Treatment Interaction terhadap peningkatan ketuntasan belajar PKn Di MTs Ar-Rusydiny Segaet Lombok Timur Tahun Pelajaran 2014/2015" diterima.

b) Penggunaan Model Pembelajaran Aptitude Treatment Interaction merupakan salah satu cara yang dapat diterapkan untuk meningkatkan kemampuan siswa yang tunjukkan dengan perbaikan hasil belajar siswa.

\section{Saran}

Berdasarkan kesimpulan dari penelitian ini, diajukan beberapa saran sebagai berikut:

a) Untuk Guru, dalam melaksanakan tugas mengajar, hendaknya mengoptimalkan penggunaan metode/model mengajar dengan memperhatikan perbedaan individual sehingga hasil belajar siswa dapat dioptimalkan.

b)Untuk Peneliti Selanjutnya, Kepada pihak-pihak yang berkepentingan untuk mengembangkan penelitian ini lebih lanjut, disarankan agar meneliti aspek-aspek yang belum terjangkau
Vol. 4, No. 2, September 2016, hal 22-29

dalam penelitian ini, sehingga diperoleh hasil yang lebih baik.

c) Untuk Siswa, yang menggunakan Model Pembelajaran Aptitude Treatment Interaction tidak jenuh dan bosan yang artinya siswa bisa tetap mempertahankan hasil belajarnya dalam kegiatan belajar mengajar disekolah.

\section{DAFTAR RUJUKAN}

Arikunto, S. 2010. Prosedur Penelitian Suatu Pendekatan Praktik Edisi Revisi 2010. Jakarta: Rineka Cipta.

Arikunto, S. 2009. Dasar-Dasar Evaluasi Pendidikan. Jakarta: Bumi Aksara.

Aqib, Z. 2002 . Profesionalisme Guru Dalam Pembelajarn. Surabaya: Percetakan Insan Cendikia.

Arifin, A. 2010. Upaya Meningkatkan Hasil Belajar Mata Pelajaran Al-Quran Hadits Melalui Model Pembelajaran Aptitude Treatment Interaction (ATI) Siswa Kelas IV MI Kebonharjo Patebon Kendal Tahun Pelajaran 2010/2011. http://repository.unri.ac.id/bitstream/123456789/1061 L1/JURNAL\%2ORIA\%2OSIYAMPRIYATI.pdf . Diakses tanggal 1 februaru pukul 19.23

BNSP.2006.Panduan Penyusunan Kurikulum Tingkat Satuan Pendidikan Jenjang Pendidikan Dasar Dan Menengah.Jakarta:BNSP

Dimyati, dkk. 2009. Belajar dan Pembelajaran. Jakarta: PT RINEKA CIPTA.

Daryono.2007. KTSP Kurikulum Tingkat Satuan Pendidikan Dasar Pemahaman Dan Pengembangan. Jakarta : Bumi

Daryanto. 1999. Evaluasi Pendidikan. Jakarta: RINEKA CIPTA

Mulyasa. 2002. kurikulum berbasis kompetensi. Bandung: REMAJA ROSDAKARYA.

Perpustakaan Universitas Indonesia. 2010. Model pembelajaran aptitude treatment interaction (ATI). http://www.google.co.id/url?sa=t\&rct=j\&q=strategi+a ptitude+treatment+interaction $+\% 28 A T I \% 29 \&$ source $=w$ eb\&cd=7\&ved=oCFEQFjAG\&url=http\%3A\%2F\%2Frepos itory.upi.edu\%2Foperator\%2Fupload\%2Fs mat 07043 43 chapter2.pdf\&ei=lvogTgjrNozSrQeJ3ay6CA\&usg=A FQjCNFp1Fss-nRsw aTvFjBoluIaQK32Q\&cad=rja, Diakses tanggal 9 januari 2013 pukul 14.34.

Ramayulis. METODELOGI Pendidikan Agama islam. Jakarta: KALAM MULYA.

Ridwan . Metode Dan Teknikmmenyusun Tesis. Bandung: ALBETA.

Rachnavia, D. 2012. Pengaruh Penggunaan Model Pembelajaran Aptitude Treatment Interaction (ATI) Terhadap Kemampuan Pemecahan masalah Matematik Peserta didik. journal. unsil. ac. id/download.php?id=217. Diakses tanggal 7 desember pukul 09.0o WITA

Slameto. 2013. Belajar dan Faktor-Faktor yang Mempengaruhinya. Jakarta : Rineka Cipta.

Sundara Komang, 2010. Diktat Kuliah Metodologi Penelitian. Universitas Muhammadiah Mataram.

Sugiyono, 2011. Metode Penelitian Pendidikan Pendekatan Kuantitatf, Kualitatif, dan R\&D. Bandung: ALBETA.

Sukmadinata, N. S. 2011. Metode penelitian pendidikan. Bandung: PT. Remaja Rosdakarya

Supriadi, F.A. Pengaruh Penerapan Model Pembelajaran Aptitude Treatment Intraction (Ati) Terhadap Hasil Belajar Siswa Materi Pokok Aljabar Kelas VII MTs Alhamidy Tahun Pelajaran 2012/2013. Skripsi tidak di publikasikan 
Suryanto,A.E. 2010. Pembelajaran berbasis Aptitude Treatmen Intraction (ATI) Untuk Meningkatkan Motivasi dan Komunkasi Belajar Matimatika Pada Garis Singgung Lingkaran (PTK di kelas VIII SMP Negri 22 Sukaraja).

http://222.124.3207.222/digilib/gdl.php?mod=brouse\&o p=read\&id=jtptiani-gdl-akhmadarif-5446. Diakses tanggal 1 Desember 2013 pukul 19.00

Winarsih dkk. 20o8. IPA Terpadu untuk SMP/MTs Kelas VII. Jakarta: Pusat Perbukuan 